\title{
Chemopreventive potential of curcumin in prostate cancer
}

\author{
Marie-Hélène Teiten $\cdot$ François Gaascht $\cdot$ \\ Serge Eifes $\cdot$ Mario Dicato $\cdot$ Marc Diederich
}

Received: 30 March 2009/Accepted: 21 September 2009/Published online: 6 October 2009

(C) Springer-Verlag 2009

\begin{abstract}
The long latency and high incidence of prostate carcinogenesis provides the opportunity to intervene with chemoprevention in order to prevent or eradicate prostate malignancies. We present here an overview of the chemopreventive potential of curcumin (diferuloylmethane), a well-known natural compound that exhibits therapeutic promise for prostate cancer. In fact, it interferes with prostate cancer proliferation and metastasis development through the down-regulation of androgen receptor and epidermal growth factor receptor, but also through the induction of cell cycle arrest. It regulates the inflammatory response through the inhibition of pro-inflammatory mediators and the NF- $\kappa \mathrm{B}$ signaling pathway. These results are consistent with this compound's ability to up-induce pro-apoptotic proteins and to down-regulate the anti-apoptotic counterparts. Alone or in combination with TRAIL-mediated immunotherapy or radiotherapy, curcumin is also reported to be a good inducer of prostate cancer cell death by apoptosis. Curcumin appears thus as a non-toxic alternative for prostate cancer prevention, treatment or co-treatment.
\end{abstract}

Keywords Curcumin - Prostate cancer .

Androgen receptor - Inflammation · Apoptosis

\section{Introduction}

Prostate diseases are among the most common malignancies in men in the Western world and prostate cancer is the

M.-H. Teiten · F. Gaascht - S. Eifes · M. Dicato

M. Diederich $(\square)$

Laboratoire de Biologie Moléculaire et Cellulaire du Cancer,

Hôpital Kirchberg, 9 rue Edward Steichen, 2540 Luxembourg,

Luxembourg

e-mail: marc.diederich@lbmcc.lu third cause of death from cancer in men. There is a huge difference in the rate of incidence of prostate cancer between Western (120 per 100,000 in Northern America) and East Asian countries (less than 10 per 100,000 in Asia) [82]. Moreover, when Asian people migrate to Western countries, their rate of prostate cancer incidence increases. This supports the idea that lifestyle, aspects of the diet and environmental factors as well as genetic factors promote prostate cancer development $[49,84,116]$. Current therapies (radical prostatectomy, chemotherapy, local radiotherapy, or hormonotherapy), although successful to treat localized, androgen-dependent, prostate cancer are of limited efficacy against androgen-independent, metastatic disease [42]. Novel treatment modalities are therefore needed to treat hormone-resistant tumors and to prevent progression of hormone-sensitive prostate cancer to the hormone-refractory stage. Primary prevention appears as an attractive strategy to eradicate prostate cancer if one considers the high prevalence of prostate cancer and the slow progressive development of healthy prostatic epithelium to dysplasia, prostatic intraepithelial neoplasia (PIN), locally invasive adenocarcinoma and finally, metastatic disease $[16,68]$.

\section{Chemoprevention with dietary phytochemicals}

Chemoprevention is a prophylactic method using non-toxic natural or synthetic compounds that reverse, inhibit, or prevent the development of cancer by inhibiting specific molecular steps in the carcinogenic pathway. The goal of chemoprevention consists in the decrease of cancer incidence, by reducing simultaneously both treatment-related side effects and mortality. Most of these natural substances are present in food, notably in fruits and vegetables. These 
chemopreventive agents regulate cell proliferation, cell survival or cell death as well as angiogenesis, and development of metastasis $[33,99,107]$.

\section{Curcumin}

Curcumin or diferuloylmethane, a polyphenolic molecule extracted from the rhizome of the plant Curcuma longa, is a promising chemopreventive compound. This natural compound is a yellow spice used as curry ingredient and is used since centuries in Ayurvedic, Chinese, and Hindu medicine systems as a potent anti-inflammatory agent. It is under investigation since several years for its major mechanisms of action and functions [3, 48, 51]. The reported studies revealed that curcumin possesses anti-oxidant [11, 56, 86], anti-inflammatory [71, 109], antiproliferative [40, 85], and anti-angiogenic [13, 117] properties against several cancer cell types [3,62] and also demonstrates anti-microbial activities [24, 26]. Nowadays, curcumin is under clinical trials mainly for cancer and related diseases (Tables 1, 2) [34, 59]. Interestingly, phase I clinical trials already demonstrated the safety of curcumin even at high doses (12 g/day); the clinical advancement of this promising natural compound is hampered by its poor water solubility and short biological half-life, resulting in low bioavailability in both plasma and tissues [5]. In fact, after oral administration of free curcumin (up to $12 \mathrm{~g} /$ day), only nanomolar concentrations of curcumin or corresponding metabolites were found in patient serum [23, 45]. A more recent phase II clinical study has pointed out that these low concentrations of curcumin were able to reach a similar biological impact on NF- $\kappa \mathrm{B}, \mathrm{COX}-2$ and phosphoSTAT-3 in peripheral blood mononuclear cells derived from treated patients than the ones observed in vitro with $5-50 \mu \mathrm{M}$ of curcumin $[34,65]$. The poor bioavailability of curcumin as well as its high hydrophobicity should be overcome for future clinical applications and i.v. administration of curcumin.
Curcumin safety and bioavailability

The potential safety of curcumin was initially demonstrated in animal models [93] and was confirmed by pharmacokinetic studies carried out in healthy human volunteers [63]. These studies revealed a high tolerance to curcumin $(0.5-12 \mathrm{~g})$ administrated orally with only few side effects (nausea, diarrhea). No free curcumin was found in the plasma of patients but glucuronide and sulfate conjugates could be detected [115]. Phase I clinical trials conducted in high-risk patients with pre-malignant or malignant lesions also presented curcumin as a safe and well-tolerated molecule even at high doses during several months [21, 23, 94, 95].

Albeit its high safety, the clinical advancement of curcumin has been hindered by its low solubility and its low bioavailability after oral administration (only $51.2 \mathrm{ng} / \mathrm{ml}$ in human serum after $12 \mathrm{~g}$ administrated orally) [5]. The low solubility ( $11 \mathrm{ng} / \mathrm{ml}$ in aqueous buffer $\mathrm{pH}$ 5.0) [113] is responsible for the poor absorption of curcumin by the human digestive tract. The low bioavailability of curcumin seems to be linked to its poor absorption, rapid metabolism, and rapid systemic elimination from the organism. In fact, the intestinal tractus is equipped with specific enzymes (UDP-glucuronosyltransferase, sulfotransferase, alcohol deshydrogenase, and p450) able to convert curcumin in relative inactive substances [57]. In order to overcome these limitations, several approaches have been tested. They include the combination of curcumin with adjuvants (e.g. piperine), and the development of delivery vehicles consisting of liposomes, nanoparticles, and phospholipid formulations of curcumin.

\section{Curcumin analogs and structure-related activity}

The comparison of curcumin with its naturally occurring analogs, corresponding to its demethoxy derivatives (demethoxycurcumin, bisdemethoxycurcumin) and to its active hydrogenated metabolites (tetrahydrocurcumin,

Table 1 Completed clinical trials with curcumin in patients affected by cancer

\begin{tabular}{llll}
\hline Subjects & Cancer type & Dose & References \\
\hline 10 volunteers & Healthy & $500 \mathrm{mg} /$ day for 1 week & Soni and Kuttan [103] \\
25 patients & Pre-malignant lesions & $500-12,000 \mathrm{mg} /$ day for 3 months & Cheng et al. [23] \\
15 patients & Advanced colorectal cancer & $18 \mathrm{mg}$ & Plummer et al. [83] \\
15 patients & Colorectal cancer & $36-180 \mathrm{mg}$ & Sharma et al. [95] \\
15 patients & Advanced colorectal cancer & $450-3,600 \mathrm{mg} /$ day for 4 months & Sharma et al. [94] \\
12 patients & Hepatic metastases from colorectal cancer & $450-3,600 \mathrm{mg} /$ day for 1 week & Garcea et al. [45] \\
12 patients & Colorectal cancer & $450-3,600 \mathrm{mg} /$ day for 1 week & Garcea et al. [46] \\
24 volunteers & Healthy & $500-12,000 \mathrm{mg} /$ day & Lao et al. [63] \\
17 patients & Advanced pancreatic cancer & $8,000 \mathrm{mg} /$ day for 2 months & Dhillon et al. [34] \\
\hline
\end{tabular}


Table 2 Ongoing clinical trials involving curcumin in patients affected by cancer

\begin{tabular}{|c|c|c|c|c|}
\hline Status & Trial name & Disease & Treatment applied & $\begin{array}{l}\text { Clinical } \\
\text { phase study }\end{array}$ \\
\hline $\begin{array}{l}\text { Active, not } \\
\text { recruiting }\end{array}$ & $\begin{array}{l}\text { Curcumin (diferuloylmethane derivative) with or } \\
\text { without bioperine in patients with multiple } \\
\text { myeloma }\end{array}$ & Multiple myeloma & Curcumin; bioperine & nd \\
\hline Recruiting & $\begin{array}{l}\text { Curcumin with pre-operative capecitabine and } \\
\text { radiation therapy followed by surgery for rectal } \\
\text { cancer }\end{array}$ & Rectal cancer & $\begin{array}{l}\text { Radiation: radiotherapy; } \\
\text { capecitabine; curcumin; } \\
\text { placebo }\end{array}$ & Phase II \\
\hline Recruiting & $\begin{array}{l}\text { Curcumin for prevention of oral mucositis in } \\
\text { children chemotherapy }\end{array}$ & $\begin{array}{l}\text { Chemotherapy induced } \\
\text { mucositis }\end{array}$ & Curcumin liquid extract & Phase III \\
\hline Completed & $\begin{array}{l}\text { Pharmacokinetics of curcumin in healthy } \\
\text { volunteers }\end{array}$ & Healthy & Curcumin & nd \\
\hline $\begin{array}{r}\text { Active, not } \\
\text { recruiting }\end{array}$ & Trial of curcumin in advanced pancreatic cancer & $\begin{array}{l}\text { Adenocarcinoma; } \\
\text { pancreatic neoplasms }\end{array}$ & Curcumin & Phase II \\
\hline $\begin{array}{r}\text { Active, not } \\
\text { recruiting }\end{array}$ & $\begin{array}{l}\text { Curcumin in preventing colon cancer in smokers } \\
\text { with aberrant crypt foci }\end{array}$ & $\begin{array}{l}\text { Colorectal cancer; } \\
\text { precancerous/ } \\
\text { nonmalignant condition }\end{array}$ & $\begin{array}{l}\text { Dietary supplement: } \\
\text { curcumin }\end{array}$ & Phase II \\
\hline Not yet recruiting & Bio-availability of a new liquid tumeric extract & Healthy & $\begin{array}{l}\text { Liquid tumeric/curcumin } \\
\text { extract }\end{array}$ & Phase I \\
\hline Recruiting & $\begin{array}{l}\text { Pilot study of curcumin formulation and } \\
\text { Ashwagandha extract in advanced } \\
\text { osteosarcoma }\end{array}$ & Osteosarcoma & $\begin{array}{l}\text { Dietary supplement: } \\
\text { curcumin powder, } \\
\text { Ashwagandha extract }\end{array}$ & Phase I and II \\
\hline Recruiting & $\begin{array}{l}\text { Gemcitabine with curcumin for pancreatic } \\
\text { cancer }\end{array}$ & Pancreatic cancer & Curcumin (+gemcitabine) & Phase II \\
\hline Not yet recruiting & $\begin{array}{l}\text { Phase III trial of gemcitabine, curcumin and } \\
\text { celebrex in patients with metastatic colon } \\
\text { cancer }\end{array}$ & Colon Neoplasm & Celecoxib; curcumin & Phase III \\
\hline Suspended & $\begin{array}{l}\text { Curcumin for treatment of intestinal adenomas in } \\
\text { familial adenomatous polyposis (FAP) }\end{array}$ & $\begin{array}{l}\text { Familial adenomatous } \\
\text { polyposis }\end{array}$ & $\begin{array}{l}\text { Dietary supplement: } \\
\text { curcumin; dietary } \\
\text { supplement: placebo }\end{array}$ & Phase II \\
\hline Recruiting & $\begin{array}{l}\text { Curcumin for treatment of intestinal adenomas in } \\
\text { familial adenomatous polyposis (FAP) }\end{array}$ & $\begin{array}{l}\text { Familial adenomatous } \\
\text { polyposis }\end{array}$ & Curcumin & nd \\
\hline Terminated & $\begin{array}{l}\text { Use of curcumin in the lower gastrointestinal } \\
\text { tract in familial adenomatous polyposis } \\
\text { patients }\end{array}$ & $\begin{array}{l}\text { Familial adenomatous } \\
\text { polyposis }\end{array}$ & Curcumin & Phase II \\
\hline Recruiting & $\begin{array}{l}\text { Phase III Trial of Gemcitabine, Curcumin and } \\
\text { Celebrex in patients with advance or } \\
\text { inoperable pancreatic cancer }\end{array}$ & Pancreatic cancer & $\begin{array}{l}\text { Gemcitabine; Curcumin; } \\
\text { Celebrex }\end{array}$ & Phase III \\
\hline Completed & Curcumin for the prevention of colon cancer & Colorectal cancer & $\begin{array}{l}\text { Dietary supplement: } \\
\text { curcumin }\end{array}$ & Phase I \\
\hline Completed & $\begin{array}{l}\text { The effects of curcuminoids on aberrant crypt } \\
\text { foci in the human colon }\end{array}$ & Aberrant crypt foci & Sulindac; curcumin & nd \\
\hline Not yet recruiting & $\begin{array}{l}\text { A nutritional supplement capsule containing } \\
\text { curcumin, green tea extract, polygonum } \\
\text { cuspidatum extract, and soybean extract in } \\
\text { healthy participants }\end{array}$ & $\begin{array}{l}\text { Healthy, no evidence of } \\
\text { disease }\end{array}$ & $\begin{array}{l}\text { Dietary supplement: } \\
\text { curcumin/green tea } \\
\text { extract/Polygonum } \\
\text { cuspidatum extract/ } \\
\text { soybean extract capsule }\end{array}$ & nd \\
\hline Suspended & $\begin{array}{l}\text { Sulindac and plant compounds in preventing } \\
\text { colon cancer }\end{array}$ & Colorectal cancer & $\begin{array}{l}\text { Dietary supplement: } \\
\text { curcumin, rutin } \\
\text { Drug: quercetin, sulindac }\end{array}$ & nd \\
\hline Recruiting & $\begin{array}{l}\text { Curcumin for the chemoprevention of colorectal } \\
\text { cancer }\end{array}$ & Adenomatous polyps & Curcuminoids & Phase II \\
\hline Recruiting & $\begin{array}{l}\text { Effect of oral curcumin on Heme-1 (HO-1) in } \\
\text { healthy male subjects }\end{array}$ & Healthy & $\begin{array}{l}\text { Dietary supplement: } \\
\text { curcumin }\end{array}$ & Phase I \\
\hline
\end{tabular}

The table was generated by using the registry of federally and privately supported clinical trials conducted in the United States and around the world (http://clinicaltrials.gov)

$n d$ non-defined 
Fig. 1 Chemical structure of curcuminoids. Curcumin (a), Curcumin demethoxy derivatives (Demethoxycurcumin and Bisdemethoxycurcumin) (b) and Curcumin hydrogenates metabolites

(Tetrahydrocurcumin, Hexahydrocurcumin and Octahydrocurcumin) (c)
A<smiles>COc1cc(/C=C/C=C(O)/C=C/c2ccc(O)c(OC)c2)ccc1O</smiles>

Curcumin

B<smiles>COc1cc(/C=C/C(O)=C/C(=O)/C=C/c2ccc(O)cc2)ccc1O</smiles>
Demethoxycurcumin<smiles>CCCCOC(C=C(O)CCc1ccc(O)c(OC)c1)CCc1ccc(O)c(OC)c1</smiles><smiles>COc1cc(CCC(O)CC(O)CCc2ccc(O)c(OC)c2)ccc1O</smiles>

hexahydrocurcumin and octahydrocurcumin) (Fig. 1) pointed out structure-activity correlations. In fact, these studies revealed that the high number of ortho-methoxy substitutions and the high level of hydrogenation of the heptadiene moiety of curcumin are responsible for the high radical scavenging potential of the curcuminoids [86, 101]. In contrast, the highest anti-inflammatory and anti-tumoral potential of curcuminoids are related to the lowest hydrogenation, to the highest level of unsaturation of the diketone moiety, and to the highest methoxylation status of the molecules [106].

Structure-activity relationships were taken into account in order to design synthetic analogs with enhanced bioactivities [6]. The modification of the basic structure of curcumin can be achieved by acetylation, alkylation, and glycosylation of the phenolic hydroxyl group as well as by alterations of the number of carbons in the middle linker chain. Glycosylation of the curcumin aromatic ring provides a more water-soluble compound with a greater kinetic stability and a good therapeutic index [43].

Several curcumin analogs have also been designed and evaluated as potential androgen receptor antagonists to be used against androgen-dependent and -independent prostate cancer cells. These experiments revealed that the co-planarity of the $\beta$-diketone moiety and the presence of strong hydrogen bond donor group were crucial for the antiandrogenic activity of these curcumin analogs. By this way, these curcumin analogs seem to be good candidates to control androgen-receptor mediated prostate cancer growth as they may function as $17 \alpha$-substituted dihydrotestosterone [81]. Following studies established an advanced structureactivity relationship for the design of new curcumin analogs<smiles>COc1cc(CCC(O)CC(O)CCc2ccc(O)c(OC)c2)ccc1O</smiles>

to be used as potential anti-prostate cancer agents. First, the aromatic rings are required for the cytotoxic and antiandrogenic activities. The $\mathrm{C}-2^{\prime}$ positions of the phenyl rings should be unsubstituted. The $\mathrm{C}-3^{\prime}$ and $\mathrm{C}-4^{\prime}$ positions should be substituted with $3^{\prime}$ and $4^{\prime}$-dimethoxy and $3^{\prime}$-methoxy-4'hydroxy substituents on the phenyl ring. Elongation of the linkers results in the loss of cytotoxicity and anti-androgenic activity. Finally, an unsaturated and conjugated linker is required for the cytotoxic and anti-androgenic activities [69]. Recent synthesis led to the design of a highly specific analog, containing a pentadienone moiety. It was reported to be 50 times more potent than curcumin to inhibit the growth of androgen-dependent and -independent prostate cancer cells with IC50 values in sub-micromolar range [44].

\section{Curcumin formulations}

To enhance the bioavailability of curcumin and to bring this natural compound to the forefront of therapeutic agents, numerous other approaches have been investigated [6].

The use of adjuvant like piperine (that inhibits UGTs and p450s), quercetin (that inhibits sulfotransferases) and genistein (that inhibits alcohol dehydrogenase) are mainly used to counteract the enzymes implicated in curcumin metabolism. Piperine from black pepper increases the bioavailability of curcumin by $154 \%$ in rats and by $2000 \%$ in humans without adverse effects [97].

On the other hand, nanoparticles, liposomes [77], micelles [64], and phospholipid complexes appear also as promising novel formulations as they provide longer circulation, lower hydrophobicity, better permeability of 
membrane barriers, and resistance to metabolic stress [5]. Curcumin encapsulated in polymeric nanoparticles demonstrates in vitro therapeutic efficacy and mechanisms of action (induction of apoptosis, inactivation of NF- $\kappa \mathrm{B} \ldots$..) comparable to free curcumin, but with a higher solubility in aqueous media [15]. Moreover, the bioavailability of encapsulated curcumin appears to be ninefold increased when compared to curcumin administered with piperine as absorption enhancer [89]. Evaluation of liposomal curcumin pointed out that this nanotechnology increases the antiproliferative properties of curcumin in prostate cancer cells with tenfold lower dose compared to free curcumin [110].

\section{Curcumin: a chemopreventive agent for prostate cancer}

Curcumin is a highly pleïotropic molecule that modulates numerous cell signaling pathways implicated in the growth and survival of several cancer cell types, including prostate cancer [1]. In the following we report the state-of-the-art concerning the chemopreventive potential of curcumin on the different stages of prostate cancer and the signaling pathways implicated (Figs. 2, 3). Curcumin was effectively shown to have a positive impact against non-cancerous chronic bacterial prostatitis [18], androgen sensitive LNCaP and 22rv1, but also against androgen-independent
DU145, and bone metastatic LNCaP-derivative C4-2B prostate cancer cells.

Down-regulation of the androgen receptors and co-factors

Androgens, including testosterone and their corresponding androgen receptors (AR), are essential for the morphogenesis and development of the prostate but are also involved into the malignant transformation of this gland [87]. Hormonotherapy by androgen depletion was thus considered as a potential treatment to eradicate prostate cancer. Unfortunately, these therapies are often ineffective as prostate cancer cells become progressively androgenindependent and lead to metastasis [42]. Uncontrolled AR gene amplification, AR mutations, and increase of AR expression appear to be a selective driving force for the progression of prostate cancer to the hormone refractory state. Curcumin was shown to have an influence on the expression level of typical prostate marker proteins. In fact, in response to curcumin treatment, the AR expression was strikingly down-regulated as well as the AR binding activity to the androgen response element of the prostatespecific antigen protein (PSA) gene, and the PSA expression in LNCaP cells $[38,76,114]$. This phenomenon is expected to deprive these cells of a critical growth advantage and classifies thus this phytochemical as a
Fig. 2 Molecular events targeted by curcumin at different stages of prostate cancer development

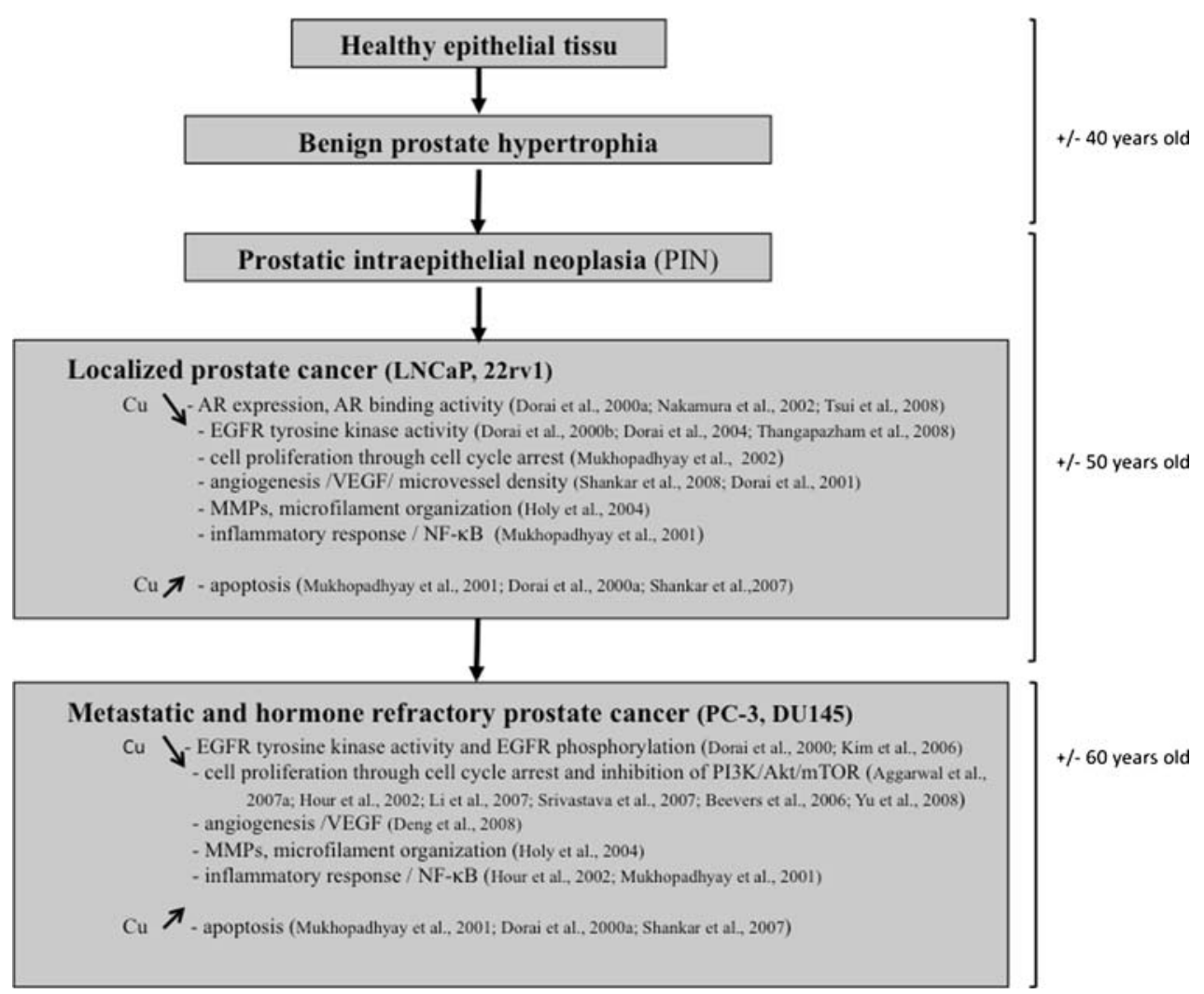


Fig. 3 Network of proteins, functional classes and cell processes modulated in prostate cancer cells after curcumin treatment. All of these data were extracted from PubMed abstracts using the MedScan Reader software (version 1.1) $[25,80]$ and then imported to the Pathway Studio software tool (Version 5.0) [78] for visualization. Nodes correspond to proteins (in red), functional classes (in orange). Lines represented the different types of interactions and relationships between the corresponding nodes and curcumin: expression (in black), regulation (in blue). Arrow line represented induction/activation, bluntended line represented repression/inactivation

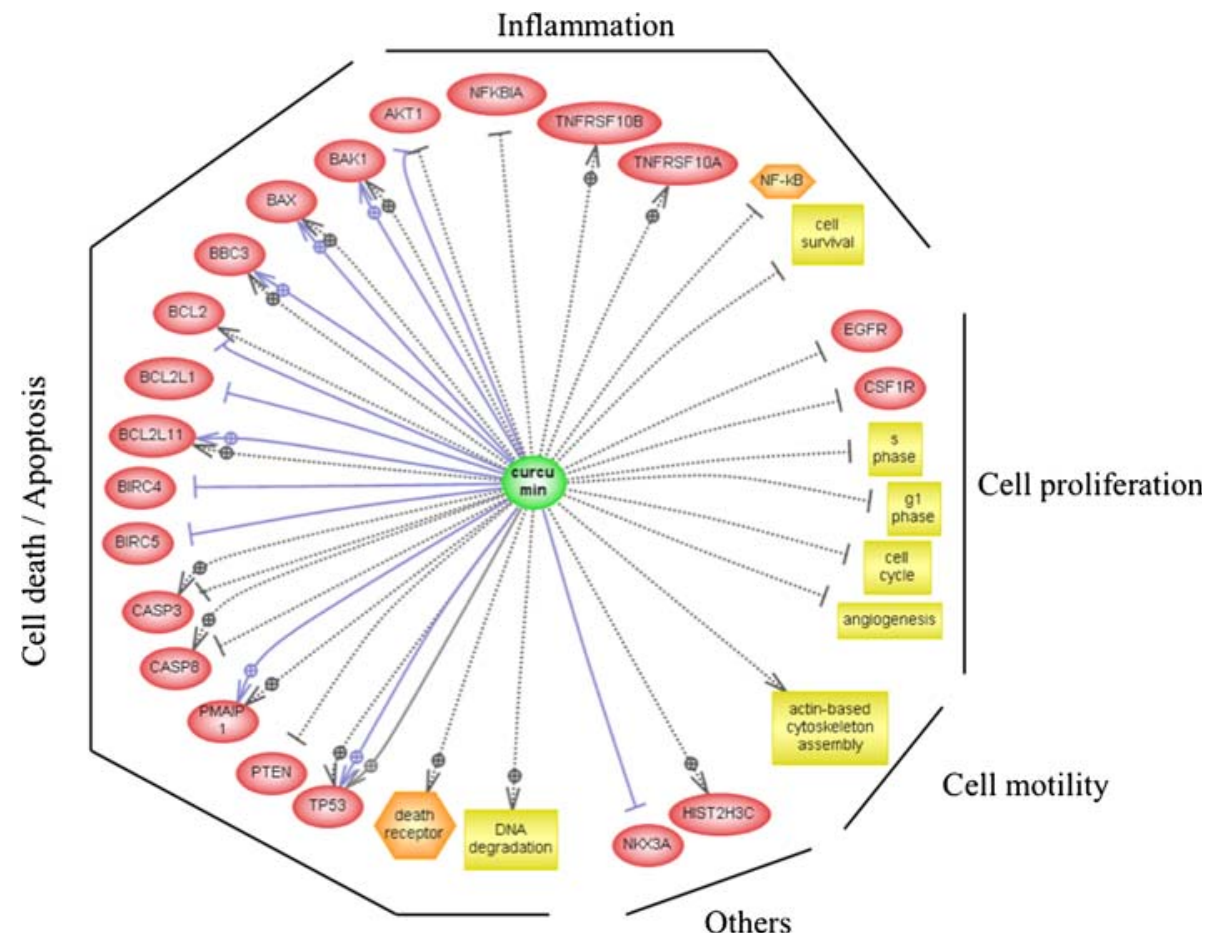

non-toxic approach to the management of AR-dependent prostate cancer [38]. Several analogs of curcumin were also shown to act as androgen receptor antagonists [81]. Such a downregulation of AR expression and the blockage of its DNA binding activity by curcumin lead also to the inhibition of the homeobox gene NKX3.1 [119], an androgen-regulated NK-class homeobox gene thought to play an important role in normal prostate organogenesis and carcinogenesis [14].

Impact on prostate cancer cell proliferation

The inappropriate and accelerated proliferation of cancer cells is linked not only to the over-expression of epidermal growth factor receptor (EGFR), to modifications of the balance between the cell cycle checkpoint and the different cyclins, but also to the deregulation of specific signaling pathways (Fig. 4).

The EGFR family, including HER2, is an important mediator of cell proliferation and is highly expressed in prostate cancer cells in which it is associated with poor prognosis [41]. Experiments performed on LNCaP and PC-3 cells revealed that curcumin is a potent inhibitor of EGFR signaling as it down-regulates the EGFR expression, inhibits the EGFR tyrosine kinase activity and the ligand-induced activation of the EGFR [39]. This polyphenolic compound was also shown to suppress the EGFR phosphorylation (Y845 and Y1068) in PC-3 cells [61]. Such results were confirmed by clustering methods and functional classification of the curcumin-gene expression profile that revealed that curcumin is able to down-regulate EGFR in LNCaP cells [111], and in cells derived from $\mathrm{LNCaP}$ with high metastatic potential in which it also inhibits the EGFR tyrosine kinase activity [37].

Curcumin was also shown to have an impact on cyclins implicated in the cell cycle. Cyclin D1, for instance, is a proto-oncogene that plays an important role in cell proliferation through the activation of cyclin-dependant kinases and is required for the progression of cells from the G1 to the $\mathrm{S}$ phase. Curcumin was shown to down-regulate cyclin D1 expression through activation of both transcriptional and post-transcriptional mechanisms in $\mathrm{LNCaP}$ prostate cancer cells [74]. Such a cell cycle arrest in G1/S phase was also observed in DU145 and PC-3 cells not only through the up-regulation of the expression of cyclindependent kinase (CDK) inhibitors p16, p21, and p27 and the inhibition of the expression of cyclin E, cyclin D1, but also through the hyperphosphorylation of retinoblastoma $(\mathrm{Rb})$ protein [104]. The down-regulation of cyclin $\mathrm{E}$ was shown to be mediated by the proteasome [2]. These effects lead to cell proliferation arrest and disruption of cell cycle control resulting in cell death by apoptosis. Others studies showed that curcumin induces an arrest in G2/M phase in PC-3 and LNCaP cells [96].

The anti-proliferative property of curcumin was confirmed in vivo by the observation of the growth of $\mathrm{LNCaP}$ cells tumors heterotypically implanted in nude mice. BrDU incorporation assays revealed that curcumin causes a marked decrease in the extent of prostate cell proliferation in mice [36], which is consistent with the observed induction of $\mathrm{p} 21$ and p27 and the inhibition of cyclin D1 [91]. 
Fig. 4 Curcumin's targets intracellular components implicated in cell proliferation signaling pathway in prostate cancer cells. Curcumin highly repressed the EGFR and VEGFR signaling pathways as well as cyclins implicated in cell cycle regulation in prostate cancer cells. Arrow line represented induction/activation and blunt-ended line represented repression/ inactivation. This figure was generated by using ScienceSlides software with modifications

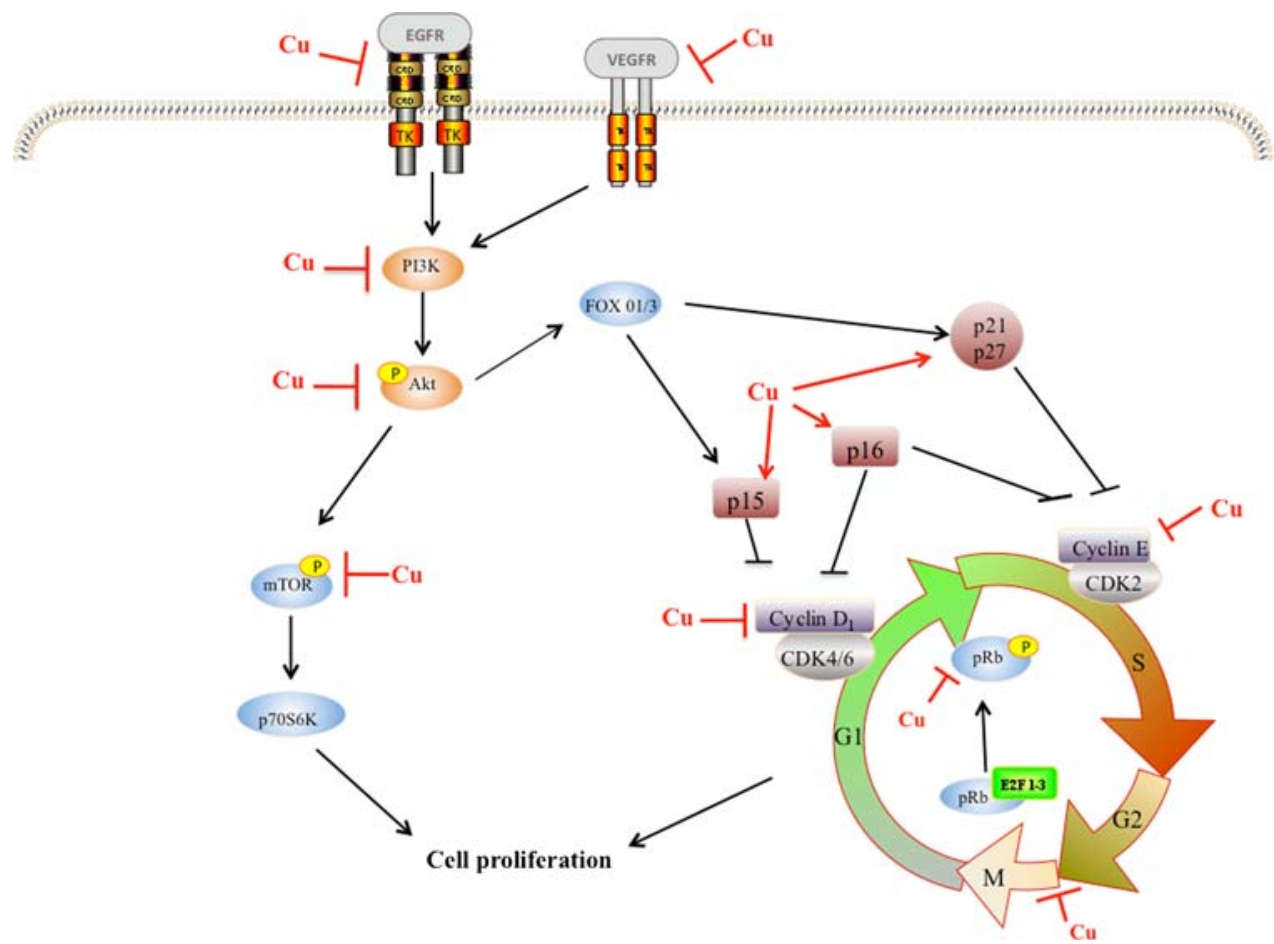

The phosphatidylinositol 3-kinase (PI3 K)/Akt (protein kinase B)/mammalian target of rapamycin (mTOR) signaling plays a central role in tumorigenesis and is often deregulated in metastatic prostate cancers through the mutation of the phosphatase and tensin homolog (PTEN) leading to the constitutive activation of Akt [20, 105]. Curcumin was shown to inhibit the phosphorylation of mTOR in DU145 [12] and PC-3 [66]. Other studies explored the molecular mechanisms implicated and revealed that curcumin activates the PP2A serine/threonine protein phosphatase and subsequently inhibits the phosphorylation of Akt/PKB, mTOR, and their downstream substrates in a concentration- and time-dependent manner in PC-3 cells leading thus to the inhibition of cell proliferation [118]. Curcumin was shown to inhibit the expression of phosphatidyl-inositol-3 kinase (PI3K) p110 and p85 subunits, and phosphorylation of Ser 473 AKT/PKB [92].

In order to stop the growth of solid tumors, it is important to block angiogenesis and its major mediator, vascular endothelial growth factor (VEGF), highly associated with metastasis development [67]. In fact, VEGF facilitates the entry of tumor cells into the blood stream and the development of distant metastasis by enhancing the hyper-permeability of vessels, the endothelial cell proliferation, and migration. VEGF is known to be highly involved in prostate cancer development [31]. Curcumin was shown to inhibit angiogenesis in vitro and in vivo [10] by suppressing the proliferation of human endothelial cells [98] and by abrogating the fibroblast growth factor-2induced angiogenic response in vivo [73]. The effect of curcumin on the regulation of angiogenesis revealed that this natural compound down-regulates the expression of pro-angiogenic genes (angiopoietin 1, angiopoietin 2, VEGF and Kinase Domain Region (KDR)) in HUVECs and EAT cells [50]. Due to the presence of NF- $\kappa$ B binding sites on the promoter of $K D R$ gene [55], the downregulation of $K D R$ gene expression could be explained by the inhibitory activity of curcumin on NF- $\kappa \mathrm{B}$ signaling.

Deng et al. [32] have reported that curcumin reduces the expression of VEGF mRNA and proteins in PC-3 cells. Similar results were obtained with LNCaP xenografts growing in nude mice in which curcumin decreased the number of VEGF receptor-2 positive endothelial cells and VEGF protein expression [91] and also the microvessel density [36].

Prevention of prostate cancer cell motility and metastasis

Highly proliferative prostate cancer cells also acquire the ability to invade surrounding tissues. Curcumin was shown to induce a marked reduction of matrix metalloproteinases (MMPs) MMP-2 and MMP-9 activity leading to a reduction of metastatic nodules in tumor-bearing mice as MMPs are known to be important prerequisite for tumor invasion and metastasis [53].

Moreover, the propensity of prostate cancer cells to establish osseous metastasis is wide as these cells are able to acquire "bone-like" properties that are facilitated by several surrounding factors. Curcumin is also able to 
counteract this potential as it was shown to inhibit the ligand-stimulated autophosphorylation of EGF-R and CSF1-R (colony stimulating factor 1 receptor) that were crucially involved in the development of osteomimetic properties of prostate cancer $\mathrm{C} 4-2 \mathrm{~B}$ cells. This natural compound is also able to inhibit the expression of the corebinding factor a-1 that is responsible for the expression of several bone-specific proteins. By this way, curcumin could inhibit the growth factor collaboration between the prostate cancer cells and the osteoblast/stromal cells in order to prevent the establishment of bone metastasis [37].

Using time-lapse video and immunofluorescence, curcumin was shown to significantly alter microfilament organization and cell motility in PC-3 and LNCaP human prostate cancer cells in vitro [52]. Curcumin increases stress fibers and the overall quantity of f-actin and also appears to be a potential inhibitor of angiogenesis and metastasis in prostate cancer.

The regulation of metastasis by curcumin was confirmed in vivo as the treatment of xenograft nude mice with curcumin results in the inhibition of MMPs and urokinase-type Plasminogen Activator (uPA) expression normally associated with the metastatic potential of prostatic cells [91].

\section{Regulation of the inflammatory response}

Inflammation emerges as a major risk factor for the development of prostate cancer and is associated with poor prognosis of treatment. In parallel, modulation of cellular signaling involved in inflammatory response (TNF $\alpha / \mathrm{NF}-$ $\kappa \mathrm{B})$ seems to be an important strategy for chemoprevention. The anti-inflammatory potential of curcumin was first described by Aggarwal and coworkers. They pointed out that curcumin inhibits the nuclear transcription factor $-\kappa \mathrm{B}$ (NF- $\kappa \mathrm{B}$ ) activation through the inhibition of $\mathrm{I} \kappa \mathrm{B} \alpha$ proteasomal degradation and thereby the nuclear translocation of p65 subunit [100]. Further investigations of curcumin mechanism of action revealed that the inhibition of p65 nuclear translocation was due to the sequential suppression of $\mathrm{I} \kappa \mathrm{B} \alpha$ kinase activity, $\mathrm{I} \kappa \mathrm{B} \alpha$ phosphorylation, $\mathrm{I} \kappa \mathrm{B} \alpha \operatorname{deg}-$ radation, p65 phosphorylation, p65 nuclear translocation, and p65 acetylation. Curcumin was also reported to inhibit the subsequent NF- $\kappa \mathrm{B}$-regulated gene expression through the inhibition of IKK and Akt activation [4]. Such an inhibitory effect of curcumin on NF- $\kappa \mathrm{B}$ activation was reported to be linked to the impairment of the proteasome function by curcumin [35, 72].

In prostate cancer cell lines and in patients affected by prostate cancer, curcumin was shown to be a promising regulator of many proteins implicated in the regulation of the inflammatory response, especially as a potent inhibitor of the constitutively activated or TNF $\alpha$-induced NF- $\kappa \mathrm{B}$ [54, 75]. Mechanistic studies revealed that curcumin inhibits the expression of NF- $\kappa \mathrm{B}$ expression by blocking the phosphorylation of $\mathrm{I} \kappa \mathrm{B} \alpha$ and its degradation by the proteasome [28], but also by suppressing the phosphorylated Akt kinase in prostate cancer cell lines [27].

Curcumin also up-regulates the mitogen-activated protein kinase phosphatase-5 (MKP5) [79]. This protein selectively dephosphorylates the jun $\mathrm{N}$-terminal kinase (JNK) and stress-activated protein kinase $\mathrm{p} 38$, that is a mediator of cellular pro-inflammatory responses, known to contribute to prostate cancer development. Downstream anti-inflammatory effects of p38 inhibition can include decreased activation of NF- $\kappa \mathrm{B}$, reduced COX-2 expression and decreased the production of pro-inflammatory cytokines such as IL-6, an autocrine growth factor for prostate cancer [47]. The subsequent decrease of COX-2 is highly relevant for prostate cancer eradication as high constitutive levels of COX-2 expression are considered as survival factors for prostate cancer [70]. So, this up-regulation of MPK5 may thus subsequently decrease pro-inflammatory signaling in both normal prostatic epithelial cells and prostate cancer cells (Fig. 5).

Induction of prostate cancer cell death by apoptosis

Prostate cancer cells express several anti-apoptotic proteins that play an important role in cell survival and resistance to conventional treatment. Using curcumin seems really interesting as this natural compound was shown to induce apoptosis in both androgen-dependent and androgen-independent prostate cancer cells (Fig. 6).

In several cancers, curcumin was shown to induce apoptosis not only through intrinsic (mitochondrial) and extrinsic (receptor-mediated) pathways but also through increased stress of the endoplasmic reticulum $[60,85]$. The intrinsic induction of apoptosis by curcumin is activated in response to cellular signals including stress or DNA damage. It implicates the up-regulation of pro-apoptotic proteins from the Bcl-2 family (Bim, Bax, Bak, Puma and Noxa) and the down-regulation of anti-apoptotic proteins (XIAP, Bcl-2, Bcl-xL). This leads to the opening of permeability transition pore, the release of cytochrome c, the activation of the apoptosome (caspase-9/apaf-1/cytochrome c) and the subsequent cleavage of caspase- $3,-6$ and -7 , Poly (ADP-ribose) polymerase (PARP), and finally the death of cells $[19,102,112]$. After curcumin treatment, the extrinsic pathway is initiated by the activation of receptors (Fas, TRAIL) at the cell surface $[9,17]$. This leads to the assembly of the DISC (death-inducing signaling complex) containing Fas, FAD, and caspase- 8 and -10 . These activated caspases converged then to the intrinsic pathway by the induction of Bid cleavage and the subsequent release of cytochrome $\mathrm{c}$, and the activation of the cascade of caspases. 
Fig. 5 Effect of curcumin on intracellular network implicated in inflammation signaling in prostate cancer cells. Curcumin regulates mainly proteins implicated in NF- $\kappa \mathrm{B}$ and AP-1 signaling. Arrow line represented induction/activation and blunt-ended line represented repression/ inactivation. This figure was generated by using

ScienceSlides software with modifications
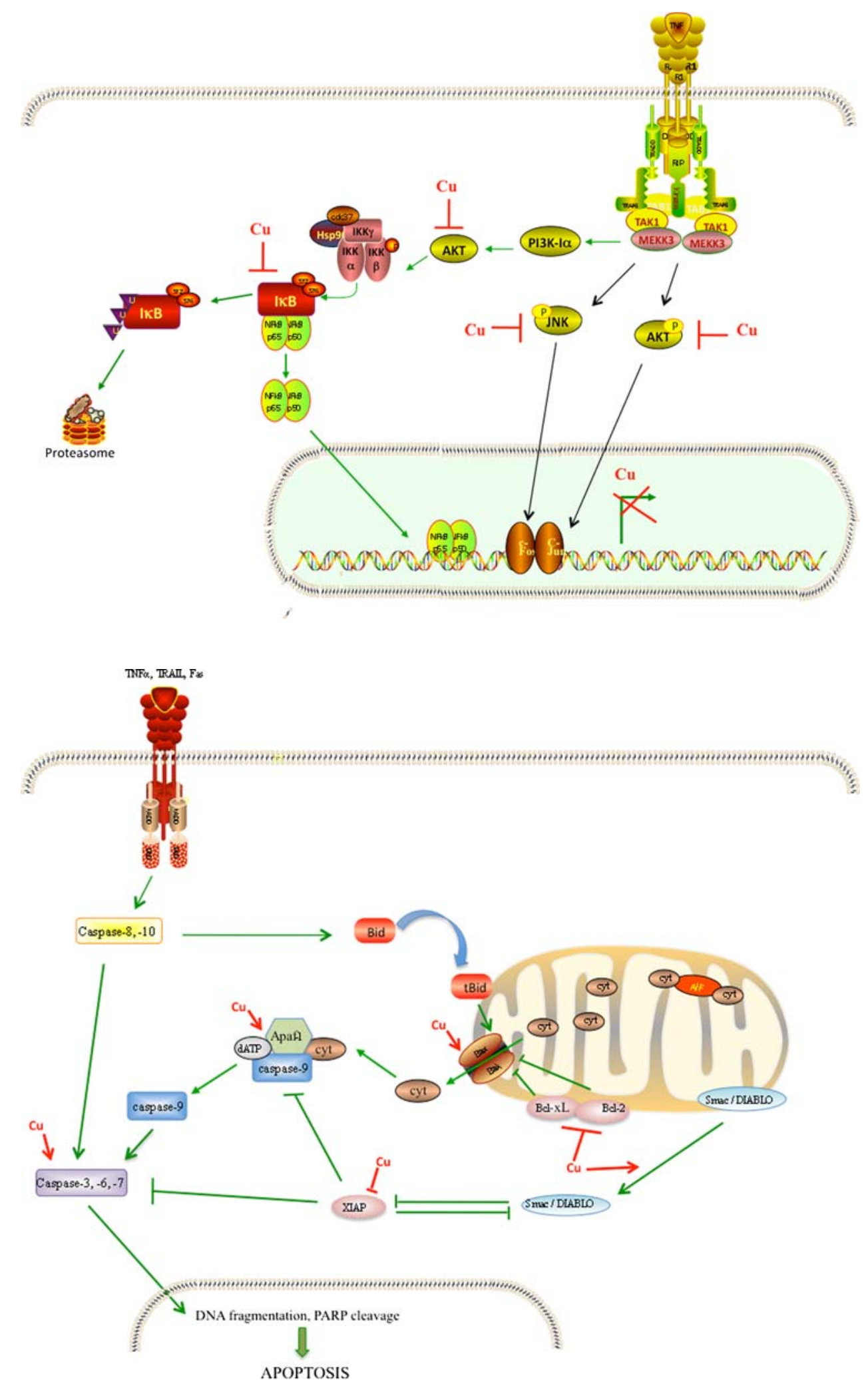

Fig. 6 Impact of curcumin on molecules implicated in signaling pathways leading to prostate cancer cell death by apoptosis. Curcumin appears as a good inhibitor of antiapoptotic proteins (Bcl-2, Bcl-xL, XIAP) and as a good inducer of pro-apoptotic proteins (Bax, Bak), of the release of cytochrome $\mathrm{c}$, and of the cascade of caspases. Arrow line represented induction/ activation and blunt-ended line represented repression/ inactivation. This figure was generated by using

ScienceSlides software with modifications
In the case of prostate cancer, several studies revealed that this natural compound is able to down-regulate apoptosis suppressor protein such as Bcl-2 and Bcl-xL and to induce the cleavage of PARP and the appearance of apoptotic figures [38, 75]. Other experiments were performed to analyze the cascade of events leading to apoptosis after curcumin treatment of prostate cancer cells. They pointed out that curcumin treatment results in the 
translocation of Bax and p53 to mitochondria, the production of reactive oxygen species, a decrease of mitochondrial membrane potential, the release of cytochrome c, Smac/DIABLO, and the activation of caspase-3. They concluded that Akt plays an important role in modulating the direct action of p53 on the caspase-dependent mitochondrial death pathway and they suggested that these important biological molecules interact at the level of the mitochondria to influence curcumin sensitivity [92]. Curcumin also down-regulates murine double minute 2 (MDM2) protein and mRNA, an important negative regulator of the p53 tumor suppressor allowing thus prostate cancer cells to undergo apoptosis [66]. The pro-apoptotic potential of curcumin was confirmed in vivo in nude mice implanted heterotypically with LNCaP cells [36].

Experiments performed on cervical cancer HeLa and neuroblastoma Neuro2a cells reported that the induction of apoptosis by curcumin, through mitochondrial pathway involving caspase- 9 activation, could also be mediated through the impairment of the ubiquitin-proteasome system [58].

Curcumin also appeared to be a good candidate to sensitize prostate cancer cells for TRAIL-mediated immunotherapy. TNF $\alpha$ related apoptosis-inducing ligand (TRAIL) is an inducer of apoptosis in many cancer cells and is an attractive cytokine for the treatment of advanced cancers including prostate cancer. Although prostate cancer cells (DU145, PC-3 and LNCaP) are mostly resistant to TRAIL, they can be sensitized with curcumin to TRAIL-induced apoptosis [28, 29, 90]. In fact, the combined curcumin and TRAIL treatment induced DNA fragmentation, the cleavage of pro-caspase-3, pro-caspase- 8 and pro-caspase- 9 , as well as the truncation of Bid and cytochrome c release [29, 30, 90]. This chemosensitization to TRAIL involved the inhibition of constitutively active NF- $\kappa \mathrm{B}$ through the suppression of $\mathrm{I} \kappa \mathrm{B} \alpha$ phosphorylation [28]. It was also related to the down-regulation of p-Akt, which leads to the inhibition of Akt-regulated NF- $\kappa \mathrm{B}$-dependent antiapoptotic Bcl-2, Bcl-xL and XIAP [27]. These results were confirmed by pre-clinical studies performed in PC-3 xenografts [8] and in TRAIL-resistant LNCaP xenografts [91].

Moreover, curcumin used in combination with radiation enhanced significantly the radiation-induced clonogenic inhibition and induced apoptosis. The combination of treatment alters the $\mathrm{Bax} / \mathrm{Bcl} 2$ ratio but activates cytochrome $\mathrm{c}$, caspase- 9 and caspase-3. This means that curcumin exhibits also a potent radiosensitizing effect in prostate cancer [22].

\section{Conclusion}

The initiation of prostate cancer from non-malignant prostate is a relative lengthy process that takes several years and is often related to fatty diet, inflammation, and oxidative stress [88]. The blockade of prostate carcinogenesis at really early stage by the use of chemopreventive molecules found mainly in our diet (fruits, vegetables, spices, seeds) appears then promising. In fact, as we reported here, curcumin is able to prevent prostate cancer initiation or progression as it inhibits inflammation signaling pathway highly implicated in prostate cancer progression through the regulation of NF- $\kappa \mathrm{B}$ and cofactors. However, despite the fact that curcumin is well described in several cancer types for its anti-oxidant potential through the induction of phase II enzymes (glutathione $S$-transferase, heme oxygenase), especially by the regulation of the transcription factor Nrf2 (nuclear factor-erythroid 2-related factor 2 erythroid) [7, 11, 108], nothing was published until today concerning prostate cancer.

Several data pointed out that curcumin is able to suppress the proliferation of both androgen-dependent and androgen-independent prostate cancer cell line but also of LNCaP xenografts by interfering with growth factor receptors, cell cycle, angiogenesis, and metastasis potential of prostate cancer cells. This natural compound also promotes the induction of prostate cancer cell death by apoptosis through a well-described cascade of events and could be useful in combination with conventional treatment such as immunotherapy and radiotherapy.

With this in mind, the use of curcumin in diet or as a treatment appears as an alternative, non toxic modality for prostate cancer prevention, treatment or co-treatment with conventional therapy by which the clinician may prevent the progression of prostate cancer to its hormone refractory state or to treat advanced prostate cancer. This also gives a rationale for the prospective of curcumin in translational studies in prostate cancer cells.

Acknowledgments M.H. Teiten and S. Eifes were supported by Télévie grants (Fonds National de la Recherche Scientifique, Belgium). F. Gaascht is recipient of an Action Lions "Vaincre le Cancer" fellowship. Dr. Diederich's research at the Laboratoire de Biologie Moléculaire et Cellulaire du Cancer (LBMCC) is financially supported by "Recherche Cancer et Sang" foundation, by «Recherches Scientifiques Luxembourg» asbl, by «Een Häerz fir Kriibskrank Kanner» association, the Action Lions "Vaincre le Cancer" Luxembourg and Televie Luxembourg. Print costs were covered by FNR, Luxembourg.

\section{References}

1. Aggarwal BB (2008) Prostate cancer and curcumin: add spice to your life. Cancer Biol Ther 7:1436-1440

2. Aggarwal BB, Banerjee S, Bharadwaj U, Sung B, Shishodia S, Sethi G (2007) Curcumin induces the degradation of cyclin E expression through ubiquitin-dependent pathway and up-regulates cyclin-dependent kinase inhibitors p21 and p27 in multiple human tumor cell lines. Biochem Pharmacol 73:1024-1032

3. Aggarwal BB, Bhatt ID, Ichikawa H, Ahn KS, Sethi G, Sandur SK, Sundaram C, Seeram N, Shishodia S (2007) Curcumin: 
biological and medicinal properties. In: Turmeric: the genus Curcuma, vol 45. CRC Press, New york

4. Aggarwal S, Ichikawa H, Takada Y, Sandur SK, Shishodia S, Aggarwal BB (2006) Curcumin (diferuloylmethane) down-regulates expression of cell proliferation and antiapoptotic and metastatic gene products through suppression of $\mathrm{I} \kappa \mathrm{B} \alpha$ kinase and Akt activation. Mol Pharmacol 69:195-206

5. Anand P, Kunnumakkara AB, Newman RA, Aggarwal BB (2007) Bioavailability of curcumin: problems and promises. Mol Pharm 4:807-818

6. Anand P, Thomas SG, Kunnumakkara AB, Sundaram C, Harikumar KB, Sung B, Tharakan ST, Misra K, Priyadarsini IK, Rajasekharan KN et al (2008) Biological activities of curcumin and its analogues (Congeners) made by man and mother nature. Biochem Pharmacol 76:1590-1611

7. Andreadi CK, Howells LM, Atherfold PA, Manson MM (2006) Involvement of Nrf2, p38, B-Raf, and nuclear factor- $\kappa \mathrm{B}$, but not phosphatidylinositol 3-kinase, in induction of hemeoxygenase-1 by dietary polyphenols. Mol Pharmacol 69:1033-1040

8. Andrzejewski T, Deeb D, Gao X, Danyluk A, Arbab AS, Dulchavsky SA, Gautam SC (2008) Therapeutic efficacy of curcumin/TRAIL combination regimen for hormone-refractory prostate cancer. Oncol Res 17:257-267

9. Anto RJ, Mukhopadhyay A, Denning K, Aggarwal BB (2002) Curcumin (diferuloylmethane) induces apoptosis through activation of caspase-8, BID cleavage and cytochrome c release: its suppression by ectopic expression of Bcl-2 and Bcl-xl. Carcinogenesis 23:143-150

10. Arbiser JL, Klauber N, Rohan R, van Leeuwen R, Huang MT, Fisher C, Flynn E, Byers HR (1998) Curcumin is an in vivo inhibitor of angiogenesis. Mol Med 4:376-383

11. Balogun E, Hoque M, Gong P, Killeen E, Green CJ, Foresti R, Alam J, Motterlini R (2003) Curcumin activates the haem oxygenase-1 gene via regulation of Nrf2 and the antioxidantresponsive element. Biochem J 371:887-895

12. Beevers CS, Li F, Liu L, Huang S (2006) Curcumin inhibits the mammalian target of rapamycin-mediated signaling pathways in cancer cells. Int J Cancer 119:757-764

13. Bhandarkar SS, Arbiser JL (2007) Curcumin as an inhibitor of angiogenesis. Adv Exp Med Biol 595:185-195

14. Bieberich CJ, Fujita K, He WW, Jay G (1996) Prostate-specific and androgen-dependent expression of a novel homeobox gene. J Biol Chem 271:31779-31782

15. Bisht S, Feldmann G, Soni S, Ravi R, Karikar C, Maitra A (2007) Polymeric nanoparticle-encapsulated curcumin ("nanocurcumin"): a novel strategy for human cancer therapy. J Nanobiotechnology 5:3

16. Bostwick DG (1996) Progression of prostatic intraepithelial neoplasia to early invasive adenocarcinoma. Eur Urol 30: 145-152

17. Bush JA, Cheung KJ Jr, Li G (2001) Curcumin induces apoptosis in human melanoma cells through a Fas receptor/caspase-8 pathway independent of p53. Exp Cell Res 271:305-314

18. Cai T, Mazzoli S, Bechi A, Addonisio P, Mondaini N, Pagliai RC, Bartoletti R (2009) Serenoa repens associated with Urtica dioica (ProstaMEV $\AA$ ) and curcumin and quercitin (FlogMEV $\left.{ }^{\circledR}\right)$ extracts are able to improve the efficacy of prulifloxacin in bacterial prostatitis patients: results from a prospective randomised study. Int J Antimicrob Agents 33:549-553

19. Cao J, Liu Y, Jia L, Zhou HM, Kong Y, Yang G, Jiang LP, Li QJ, Zhong LF (2007) Curcumin induces apoptosis through mitochondrial hyperpolarization and mtDNA damage in human hepatoma G2 cells. Free Radic Biol Med 43:968-975

20. Carnero A, Blanco-Aparicio C, Renner O, Link W, Leal JF (2008) The PTEN/PI3K/AKT signalling pathway in cancer, therapeutic implications. Curr Cancer Drug Targets 8:187-198
21. Chainani-Wu N (2003) Safety and anti-inflammatory activity of curcumin: a component of tumeric (Curcuma longa). J Altern Complement Med 9:161-168

22. Chendil D, Ranga RS, Meigooni D, Sathishkumar S, Ahmed MM (2004) Curcumin confers radiosensitizing effect in prostate cancer cell line PC-3. Oncogene 23:1599-1607

23. Cheng AL, Hsu CH, Lin JK, Hsu MM, Ho YF, Shen TS, Ko JY, Lin JT, Lin BR, Ming-Shiang W et al (2001) Phase I clinical trial of curcumin, a chemopreventive agent, in patients with high-risk or pre-malignant lesions. Anticancer Res 21:28952900

24. Cui L, Miao J (2007) Cytotoxic effect of curcumin on malaria parasite Plasmodium falciparum: inhibition of histone acetylation and generation of reactive oxygen species. Antimicrob Agents Chemother 51:488-494

25. Daraselia N, Yuryev A, Egorov S, Novichkova S, Nikitin A, Mazo I (2004) Extracting human protein interactions from MEDLINE using a full-sentence parser. Bioinformatics 20: 604-611

26. De R, Kundu P, Swarnakar S, Ramamurthy T, Chowdhury A, Nair GB, Mukhopadhyay AK (2009) Antimicrobial activity of curcumin against Indian Helicobacter pylori and also during mice infection. Antimicrob Agents Chemother 53:1592-1597

27. Deeb D, Jiang H, Gao X, Al-Holou S, Danyluk AL, Dulchavsky SA, Gautam SC (2007) Curcumin [1, 7-bis(4-hydroxy-3-methoxyphenyl)-1-6-heptadine-3, 5-dione; C21H20O6] sensitizes human prostate cancer cells to tumor necrosis factor-related apoptosis-inducing ligand/Apo2L-induced apoptosis by suppressing nuclear factor-kappaB via inhibition of the prosurvival Akt signaling pathway. J Pharmacol Exp Ther 321:616-625

28. Deeb D, Jiang H, Gao X, Hafner MS, Wong H, Divine G, Chapman RA, Dulchavsky SA, Gautam SC (2004) Curcumin sensitizes prostate cancer cells to tumor necrosis factor-related apoptosis-inducing ligand/Apo2L by inhibiting nuclear factorkappaB through suppression of IkappaBalpha phosphorylation. Mol Cancer Ther 3:803-812

29. Deeb D, Xu YX, Jiang H, Gao X, Janakiraman N, Chapman RA, Gautam SC (2003) Curcumin (diferuloyl-methane) enhances tumor necrosis factor-related apoptosis-inducing ligand-induced apoptosis in LNCaP prostate cancer cells. Mol Cancer Ther 2:95-103

30. Deeb DD, Jiang H, Gao X, Divine G, Dulchavsky SA, Gautam SC (2005) Chemosensitization of hormone-refractory prostate cancer cells by curcumin to TRAIL-induced apoptosis. J Exp Ther Oncol 5:81-91

31. Delongchamps NB, Peyromaure M, Dinh-Xuan AT (2006) Role of vascular endothelial growth factor in prostate cancer. Urology 68:244-248

32. Deng G, Yu JH, Ye ZQ, Hu ZQ (2008) Curcumin inhibits the expression of vascular endothelial growth factor and androgenindependent prostate cancer cell line PC-3 in vitro. Zhonghua Nan Ke Xue 14:116-121

33. Deorukhkar A, Krishnan S, Sethi G, Aggarwal BB (2007) Back to basics: how natural products can provide the basis for new therapeutics. Expert Opin Investig Drugs 16:1753-1773

34. Dhillon N, Aggarwal BB, Newman RA, Wolff RA, Kunnumakkara AB, Abbruzzese JL, Ng CS, Badmaev V, Kurzrock R (2008) Phase II trial of curcumin in patients with advanced pancreatic cancer. Clin Cancer Res 14:4491-4499

35. Dikshit P, Goswami A, Mishra A, Chatterjee M, Jana NR (2006) Curcumin induces stress response, neurite outgrowth and prevent NF-kappaB activation by inhibiting the proteasome function. Neurotox Res 9:29-37

36. Dorai T, Cao YC, Dorai B, Buttyan R, Katz AE (2001) Therapeutic potential of curcumin in human prostate cancer. III. Curcumin inhibits proliferation, induces apoptosis, and inhibits 
angiogenesis of $\mathrm{LNCaP}$ prostate cancer cells in vivo. Prostate 47:293-303

37. Dorai T, Dutcher JP, Dempster DW, Wiernik PH (2004) Therapeutic potential of curcumin in prostate cancer-V: interference with the osteomimetic properties of hormone refractory C4-2B prostate cancer cells. Prostate 60:1-17

38. Dorai T, Gehani N, Katz A (2000) Therapeutic potential of curcumin in human prostate cancer-I. Curcumin induces apoptosis in both androgen-dependent and androgen-independent prostate cancer cells. Prostate Cancer Prostatic Dis 3:84-93

39. Dorai T, Gehani N, Katz A (2000) Therapeutic potential of curcumin in human prostate cancer-II. Curcumin inhibits tyrosine kinase activity of epidermal growth factor receptor and depletes the protein. Mol Urol 4:1-6

40. Duvoix A, Blasius R, Delhalle S, Schnekenburger M, Morceau F, Henry E, Dicato M, Diederich M (2005) Chemopreventive and therapeutic effects of curcumin. Cancer Lett 223:181-190

41. Edwards J, Mukherjee R, Munro AF, Wells AC, Almushatat A, Bartlett JM (2004) HER2 and COX2 expression in human prostate cancer. Eur J Cancer 40:50-55

42. Feldman BJ, Feldman D (2001) The development of androgenindependent prostate cancer. Nat Rev Cancer 1:34-45

43. Ferrari E, Lazzari S, Marverti G, Pignedoli F, Spagnolo F, Saladini M (2009) Synthesis, cytotoxic and combined cDDP activity of new stable curcumin derivatives. Bioorg Med Chem 17:3043-3052

44. Fuchs JR, Pandit B, Bhasin D, Etter JP, Regan N, Abdelhamid D, Li C, Lin J, Li PK (2009) Structure-activity relationship studies of curcumin analogues. Bioorg Med Chem Lett 19: 2065-2069

45. Garcea G, Jones DJ, Singh R, Dennison AR, Farmer PB, Sharma RA, Steward WP, Gescher AJ, Berry DP (2004) Detection of curcumin and its metabolites in hepatic tissue and portal blood of patients following oral administration. Br J Cancer 90:10111015

46. Garcea G, Berry DP, Jones DJ, Singh R, Dennison AR, Farmer PB, Sharma RA, Steward WP, Gescher AJ (2005) Consumption of the putative chemopreventive agent curcumin by cancer patients: assessment of curcumin levels in the colorectum and their pharmacodynamic consequences. Cancer Epidemiol Biomarkers Prev 14:120-125

47. Giri D, Ozen M, Ittmann M (2001) Interleukin-6 is an autocrine growth factor in human prostate cancer. Am J Pathol 159: 2159-2165

48. Goel A, Kunnumakkara AB, Aggarwal BB (2008) Curcumin as "Curecumin": from kitchen to clinic. Biochem Pharmacol 75:787-809

49. Gronberg H (2003) Prostate cancer epidemiology. Lancet 361:859-864

50. Gururaj AE, Belakavadi M, Venkatesh DA, Marme D, Salimath BP (2002) Molecular mechanisms of anti-angiogenic effect of curcumin. Biochem Biophys Res Commun 297:934-942

51. Hatcher H, Planalp R, Cho J, Torti FM, Torti SV (2008) Curcumin: from ancient medicine to current clinical trials. Cell Mol Life Sci 65:1631-1652

52. Holy J (2004) Curcumin inhibits cell motility and alters microfilament organization and function in prostate cancer cells. Cell Motil Cytoskeleton 58:253-268

53. Hong JH, Ahn KS, Bae E, Jeon SS, Choi HY (2006) The effects of curcumin on the invasiveness of prostate cancer in vitro and in vivo. Prostate Cancer Prostatic Dis 9:147-152

54. Hour TC, Chen J, Huang CY, Guan JY, Lu SH, Pu YS (2002) Curcumin enhances cytotoxicity of chemotherapeutic agents in prostate cancer cells by inducing $\mathrm{p} 21$ (WAF1/CIP1) and C/EBPbeta expressions and suppressing NF-kappaB activation. Prostate $51: 211-218$
55. Illi B, Puri P, Morgante L, Capogrossi MC, Gaetano C (2000) Nuclear factor-kappaB and cAMP response element binding protein mediate opposite transcriptional effects on the Flk-1/ KDR gene promoter. Circ Res 86:E110-E117

56. Iqbal M, Okazaki Y, Okada S (2009) Curcumin attenuates oxidative damage in animals treated with a renal carcinogen, ferric nitrilotriacetate (Fe-NTA): implications for cancer prevention. Mol Cell Biochem 324:157-164

57. Ireson CR, Jones DJ, Orr S, Coughtrie MW, Boocock DJ, Williams ML, Farmer PB, Steward WP, Gescher AJ (2002) Metabolism of the cancer chemopreventive agent curcumin in human and rat intestine. Cancer Epidemiol Biomarkers Prev $11: 105-111$

58. Jana NR, Dikshit P, Goswami A, Nukina N (2004) Inhibition of proteasomal function by curcumin induces apoptosis through mitochondrial pathway. J Biol Chem 279:11680-11685

59. Johnson JJ, Mukhtar H (2007) Curcumin for chemoprevention of colon cancer. Cancer Lett 255:170-181

60. Khan N, Adhami VM, Mukhtar H (2008) Apoptosis by dietary agents for prevention and treatment of cancer. Biochem Pharmacol 76:1333-1339

61. Kim JH, Xu C, Keum YS, Reddy B, Conney A, Kong AN (2006) Inhibition of EGFR signaling in human prostate cancer PC-3 cells by combination treatment with beta-phenylethyl isothiocyanate and curcumin. Carcinogenesis 27:475-482

62. Kunnumakkara AB, Anand P, Aggarwal BB (2008) Curcumin inhibits proliferation, invasion, angiogenesis and metastasis of different cancers through interaction with multiple cell signaling proteins. Cancer Lett 269:199-225

63. Lao CD, Ruffin MTT, Normolle D, Heath DD, Murray SI, Bailey JM, Boggs ME, Crowell J, Rock CL, Brenner DE (2006) Dose escalation of a curcuminoid formulation. BMC Complement Altern Med 6:10

64. Lapenna S, Bilia AR, Morris GA, Nilsson M (2009) Novel artemisinin and curcumin micellar formulations: drug solubility studies by NMR spectroscopy. J Pharm Sci 98(10):3666-3675

65. Li L, Aggarwal BB, Shishodia S, Abbruzzese J, Kurzrock R (2004) Nuclear factor-kappaB and IkappaB kinase are constitutively active in human pancreatic cells, and their down-regulation by curcumin (diferuloylmethane) is associated with the suppression of proliferation and the induction of apoptosis. Cancer 101:2351-2362

66. Li M, Zhang Z, Hill DL, Wang H, Zhang R (2007) Curcumin, a dietary component, has anticancer, chemosensitization, and radiosensitization effects by down-regulating the MDM2 oncogene through the PI3K/mTOR/ETS2 pathway. Cancer Res 67:1988-1996

67. Li Y, Cozzi PJ (2009) Angiogenesis as a strategic target for prostate cancer therapy. Med Res Rev

68. Lieberman R, Bermejo C, Akaza H, Greenwald P, Fair W, Thompson I (2001) Progress in prostate cancer chemoprevention: modulators of promotion and progression. Urology 58:835-842

69. Lin L, Shi Q, Nyarko AK, Bastow KF, Wu CC, Su CY, Shih CC, Lee KH (2006) Antitumor agents. 250. Design and synthesis of new curcumin analogues as potential anti-prostate cancer agents. J Med Chem 49:3963-3972

70. Liu XH, Yao S, Kirschenbaum A, Levine AC (1998) NS398, a selective cyclooxygenase-2 inhibitor, induces apoptosis and down-regulates bcl-2 expression in $\mathrm{LNCaP}$ cells. Cancer Res 58:4245-4249

71. Menon VP, Sudheer AR (2007) Antioxidant and anti-inflammatory properties of curcumin. Adv Exp Med Biol 595:105-125

72. Milacic V, Banerjee S, Landis-Piwowar KR, Sarkar FH, Majumdar AP, Dou QP (2008) Curcumin inhibits the proteasome activity in human colon cancer cells in vitro and in vivo. Cancer Res 68:7283-7292 
73. Mohan R, Sivak J, Ashton P, Russo LA, Pham BQ, Kasahara N, Raizman MB, Fini ME (2000) Curcuminoids inhibit the angiogenic response stimulated by fibroblast growth factor-2, including expression of matrix metalloproteinase gelatinase B. J Biol Chem 275:10405-10412

74. Mukhopadhyay A, Banerjee S, Stafford LJ, Xia C, Liu M, Aggarwal BB (2002) Curcumin-induced suppression of cell proliferation correlates with down-regulation of cyclin D1 expression and CDK4-mediated retinoblastoma protein phosphorylation. Oncogene 21:8852-8861

75. Mukhopadhyay A, Bueso-Ramos C, Chatterjee D, Pantazis P, Aggarwal BB (2001) Curcumin downregulates cell survival mechanisms in human prostate cancer cell lines. Oncogene 20:7597-7609

76. Nakamura K, Yasunaga Y, Segawa T, Ko D, Moul JW, Srivastava S, Rhim JS (2002) Curcumin down-regulates AR gene expression and activation in prostate cancer cell lines. Int $\mathbf{J}$ Oncol 21:825-830

77. Narayanan NK, Nargi D, Randolph C, Narayanan BA (2009) Liposome encapsulation of curcumin and resveratrol in combination reduces prostate cancer incidence in PTEN knockout mice. Int J Cancer 125:1-8

78. Nikitin A, Egorov S, Daraselia N, Mazo I (2003) Pathway studio-the analysis and navigation of molecular networks. Bioinformatics 19:2155-2157

79. Nonn L, Duong D, Peehl DM (2007) Chemopreventive antiinflammatory activities of curcumin and other phytochemicals mediated by MAP kinase phosphatase- 5 in prostate cells. Carcinogenesis 28:1188-1196

80. Novichkova S, Egorov S, Daraselia N (2003) MedScan, a natural language processing engine for MEDLINE abstracts. Bioinformatics 19:1699-1706

81. Ohtsu H, Xiao Z, Ishida J, Nagai M, Wang HK, Itokawa H, Su CY, Shih C, Chiang T, Chang E et al (2002) Antitumor agents. 217. Curcumin analogues as novel androgen receptor antagonists with potential as anti-prostate cancer agents. J Med Chem 45:5037-5042

82. Parkin DM, Bray F, Ferlay J, Pisani P (2005) Global cancer statistics, 2002. CA Cancer J Clin 55:74-108

83. Plummer SM, Hill KA, Festing MF, Steward WP, Gescher AJ, Sharma RA (2001) Clinical development of leukocyte cyclooxygenase 2 activity as a systemic biomarker for cancer chemopreventive agents. Cancer Epidemiol Biomarkers Prev 10:1295-1299

84. Rastogi T, Devesa S, Mangtani P, Mathew A, Cooper N, Kao R, Sinha R (2008) Cancer incidence rates among South Asians in four geographic regions: India, Singapore, UK and US. Int J Epidemiol 37:147-160

85. Reuter S, Eifes S, Dicato M, Aggarwal BB, Diederich M (2008) Modulation of anti-apoptotic and survival pathways by curcumin as a strategy to induce apoptosis in cancer cells. Biochem Pharmacol 76:1340-1351

86. Sandur SK, Pandey MK, Sung B, Ahn KS, Murakami A, Sethi G, Limtrakul P, Badmaev V, Aggarwal BB (2007) Curcumin, demethoxycurcumin, bisdemethoxycurcumin, tetrahydrocurcumin and turmerones differentially regulate anti-inflammatory and anti-proliferative responses through a ROS-independent mechanism. Carcinogenesis 28:1765-1773

87. Schulz WA, Burchardt M, Cronauer MV (2003) Molecular biology of prostate cancer. Mol Hum Reprod 9:437-448

88. Sciarra A, Mariotti G, Salciccia S, Gomez AA, Monti S, Toscano V, Di Silverio F (2008) Prostate growth and inflammation. J Steroid Biochem Mol Biol 108:254-260

89. Shaikh J, Ankola DD, Beniwal V, Singh D, Kumar MN (2009) Nanoparticle encapsulation improves oral bioavailability of curcumin by at least 9-fold when compared to curcumin administered with piperine as absorption enhancer. Eur J Pharm Sci 37:223-230

90. Shankar S, Chen Q, Sarva K, Siddiqui I, Srivastava RK (2007) Curcumin enhances the apoptosis-inducing potential of TRAIL in prostate cancer cells: molecular mechanisms of apoptosis, migration and angiogenesis. J Mol Signal 2:10

91. Shankar S, Ganapathy S, Chen Q, Srivastava RK (2008) Curcumin sensitizes TRAIL-resistant xenografts: molecular mechanisms of apoptosis, metastasis and angiogenesis. Mol Cancer 7:16

92. Shankar S, Srivastava RK (2007) Involvement of Bcl-2 family members, phosphatidylinositol 3'-kinase/AKT and mitochondrial p53 in curcumin (diferulolylmethane)-induced apoptosis in prostate cancer. Int J Oncol 30:905-918

93. Shankar TN, Shantha NV, Ramesh HP, Murthy IA, Murthy VS (1980) Toxicity studies on turmeric (Curcuma longa): acute toxicity studies in rats, guineapigs \& monkeys. Indian J Exp Biol 18:73-75

94. Sharma RA, Euden SA, Platton SL, Cooke DN, Shafayat A, Hewitt HR, Marczylo TH, Morgan B, Hemingway D, Plummer SM et al (2004) Phase I clinical trial of oral curcumin: biomarkers of systemic activity and compliance. Clin Cancer Res 10:6847-6854

95. Sharma RA, McLelland HR, Hill KA, Ireson CR, Euden SA, Manson MM, Pirmohamed M, Marnett LJ, Gescher AJ, Steward WP (2001) Pharmacodynamic and pharmacokinetic study of oral Curcuma extract in patients with colorectal cancer. Clin Cancer Res 7:1894-1900

96. Shenouda NS, Zhou C, Browning JD, Ansell PJ, Sakla MS, Lubahn DB, Macdonald RS (2004) Phytoestrogens in common herbs regulate prostate cancer cell growth in vitro. Nutr Cancer 49:200-208

97. Shoba G, Joy D, Joseph T, Majeed M, Rajendran R, Srinivas PS (1998) Influence of piperine on the pharmacokinetics of curcumin in animals and human volunteers. Planta Med 64:353-356

98. Singh AK, Sidhu GS, Deepa T, Maheshwari RK (1996) Curcumin inhibits the proliferation and cell cycle progression of human umbilical vein endothelial cell. Cancer Lett 107:109-115

99. Singh RP, Agarwal R (2006) Mechanisms of action of novel agents for prostate cancer chemoprevention. Endocr Relat Cancer 13:751-778

100. Singh S, Aggarwal BB (1995) Activation of transcription factor NF-kappa B is suppressed by curcumin (diferuloylmethane) [corrected]. J Biol Chem 270:24995-25000

101. Somparn P, Phisalaphong C, Nakornchai S, Unchern S, Morales NP (2007) Comparative antioxidant activities of curcumin and its demethoxy and hydrogenated derivatives. Biol Pharm Bull 30:74-78

102. Song G, Mao YB, Cai QF, Yao LM, Ouyang GL, Bao SD (2005) Curcumin induces human HT-29 colon adenocarcinoma cell apoptosis by activating p53 and regulating apoptosis-related protein expression. Braz J Med Biol Res 38:1791-1798

103. Soni KB, Kuttan R (1992) Effect of oral curcumin administration on serum peroxides and cholesterol levels in human volunteers. Indian J Physiol Pharmacol 36:273-275

104. Srivastava RK, Chen Q, Siddiqui I, Sarva K, Shankar S (2007) Linkage of curcumin-induced cell cycle arrest and apoptosis by cyclin-dependent kinase inhibitor p21(/WAF1/CIP1). Cell Cycle 6:2953-2961

105. Steelman LS, Stadelman KM, Chappell WH, Horn S, Basecke J, Cervello M, Nicoletti F, Libra M, Stivala F, Martelli AM et al (2008) Akt as a therapeutic target in cancer. Expert Opin Ther Targets 12:1139-1165

106. Sugiyama Y, Kawakishi S, Osawa T (1996) Involvement of the beta-diketone moiety in the antioxidative mechanism of tetrahydrocurcumin. Biochem Pharmacol 52:519-525 
107. Surh YJ (2003) Cancer chemoprevention with dietary phytochemicals. Nat Rev Cancer 3:768-780

108. Surh YJ, Na HK (2008) NF-kappaB and Nrf2 as prime molecular targets for chemoprevention and cytoprotection with anti-inflammatory and antioxidant phytochemicals. Genes Nutr 2:313-317

109. Teiten MH, Reuter S, Schmucker S, Dicato M, Diederich M (2009) Gene expression profiling related to anti-inflammatory properties of curcumin in K562 leukemia cells. Ann N Y Acad Sci 1171:391-398

110. Thangapazham RL, Puri A, Tele S, Blumenthal R, Maheshwari RK (2008) Evaluation of a nanotechnology-based carrier for delivery of curcumin in prostate cancer cells. Int J Oncol 32:1119-1123

111. Thangapazham RL, Shaheduzzaman S, Kim KH, Passi N, Tadese A, Vahey M, Dobi A, Srivastava S, Maheshwari RK (2008) Androgen responsive and refractory prostate cancer cells exhibit distinct curcumin regulated transcriptome. Cancer Biol Ther 7:1427-1435

112. Tian B, Wang Z, Zhao Y, Wang D, Li Y, Ma L, Li X, Li J, Xiao N, Tian J et al (2008) Effects of curcumin on bladder cancer cells and development of urothelial tumors in a rat bladder carcinogenesis model. Cancer Lett 264:299-308

113. Tonnesen HH, Masson M, Loftsson T (2002) Studies of curcumin and curcuminoids. XXVII. Cyclodextrin complexation: solubility, chemical and photochemical stability. Int J Pharm 244:127-135
114. Tsui KH, Feng TH, Lin CM, Chang PL, Juang HH (2008) Curcumin blocks the activation of androgen and interlukin- 6 on prostate-specific antigen expression in human prostatic carcinoma cells. J Androl 29:661-668

115. Vareed SK, Kakarala M, Ruffin MT, Crowell JA, Normolle DP, Djuric Z, Brenner DE (2008) Pharmacokinetics of curcumin conjugate metabolites in healthy human subjects. Cancer Epidemiol Biomarkers Prev 17:1411-1417

116. Whittemore AS, Kolonel LN, Wu AH, John EM, Gallagher RP, Howe GR, Burch JD, Hankin J, Dreon DM, West DW et al (1995) Prostate cancer in relation to diet, physical activity, and body size in blacks, whites, and Asians in the United States and Canada. J Natl Cancer Inst 87:652-661

117. Yoysungnoen $\mathrm{P}$, Wirachwong $\mathrm{P}$, Changtam C, Suksamrarn A, Patumraj S (2008) Anti-cancer and anti-angiogenic effects of curcumin and tetrahydrocurcumin on implanted hepatocellular carcinoma in nude mice. World J Gastroenterol 14:2003-2009

118. Yu S, Shen G, Khor TO, Kim JH, Kong AN (2008) Curcumin inhibits Akt/mammalian target of rapamycin signaling through protein phosphatase-dependent mechanism. Mol Cancer Ther 7:2609-2620

119. Zhang HN, Yu CX, Zhang PJ, Chen WW, Jiang AL, Kong F, Deng JT, Zhang JY, Young CY (2007) Curcumin downregulates homeobox gene NKX3.1 in prostate cancer cell LNCaP. Acta Pharmacol Sin 28:423-430 